日植病報 $48: 1-8$ (1982)

Ann. Phytopath. Soc. Japan $48: 1-8$ (1982)

\title{
Biological and Chemical Properties of Slime Polysaccharide of Xanthomonas campestris pv. oryzae
}

\author{
Jae Eul Choi*, Nobuaki Matsuyama* and Satoshi Wakimoto* \\ 崔 在乙*・松山宣明*・脇本 哲* $:$ イネ白葉怙病菌粘液 \\ 多糖質の生物学的抒よび化学的性質
}

\begin{abstract}
The slime polysaccharide of $X$. campestris pv. oryzae caused wilting in rice cuttings. This substance was high molecular and was precipitated by ethanol. Wilt inducing potential of slime polysaccharides of virulent and avirulent clones could not be differentiated. The slime polysaccharide of all clones was composed of arabitol, mannose, glucuronolactone, glucose and glucuronic acid. The ratios of these sugars were quite different between large colony type and small colony type. In general, arabitol and glucose contents of slime polysaccharides were higher in small colony types ( $\mathrm{St}$ and $\mathrm{Sm}$ ) than in large colony types ( $\mathrm{Lw}, \mathrm{Ld}$ and $\mathrm{Lh}$ ). Column chromatography on Sephadex G-200 revealed that the slime polysaccharides of each clone were heterogeneous in molecular weight. The wild type was composed of relatively greater amount of high molecular weight polysaccharide whereas the small colony type variants were of relatively low molecular ones. Intermediate types such as $\mathrm{Ld}$ and $\mathrm{Lh}$ were composed of both these types.

The hapten inhibition studies were carried out by using sugars of slime polysaccharide component and anti-Q7472-serum. In the case of the isolate Q7472 (serovar A), glucose, mannose and glucuronic acid inhibited precipitin reaction, while in the cases of Q7502 (serovar B-I) and N 5837 (serovar B-II), glucuronic acid and glucuronolactone were strong promotors of the precipitin reaction. These facts suggest that the component sugars of a major portion of the immunogenic regions are remarkably different with serovars.
\end{abstract}

(Received June 19, 1981)

Key Words: Xanthomonas campestris pv. oryzae, virulence, bacteriological properties.

\section{Introduction}

The surface of gram-negative bacterial cells is covered with extracellular polysaccharide (EPS) and lipopolysaccharide, which have been implicated as determinants in pathogenesis to animals and human-beings ${ }^{26)}$. The production of EPS in form of capsule and loose slime are also known to be associated with virulence in several plant pathogenic bacteria ${ }^{2,9,12,14,16}$. These polysaccharides are thought to be involved in symptom expression, i.e., wilting due to decreased vascular flow ${ }^{3,10,12,14,31)}$, and it has been suggested that the production of EPS may interfere with defense mechanism of host plants which involves recognition of alien bacterial cell-wall component such as lipopolysaccharide ${ }^{25}$.

\footnotetext{
* Faculty of Agriculture, Kyushu University, Fukuoka 812, Japan九州大学農学部
} 
Cadmus et $a ._{.}{ }^{4)}$ reported that extracellular polysaccharide produced by the small colony type variants differed in solution properties from that of parent strain (large colony type) in $X$. campestris pv. campestris; it differed also in content of pyruvic acid and O-acetyl substituents. However, the polysaccharides of normal and variant strains were identical in molar ratios of sugars. Kuo et al. ${ }^{20)}$ reported that $X$. campestris pv. oryzae produced polysaccharides which could induce wilting in plant cuttings. Fan and $\mathrm{Kuo}^{13)}$ and $\mathrm{Tabei}^{{ }^{30)}}$ attributed this polysaccharide induced-wilting to plugging of xylem vessels.

According to the report of Misaki et al. ${ }^{22)}$ extracellular polysaccharide of $X$. campestris pv. oryzae contains glucose, mannose and glucuronic acid, while others ${ }^{1,20)}$ reported that glucose, mannose, glucuronic acid and glucuronolactone may be the constituents.

In this experiment the relationships among colony types, serological properties, wilt inducing ability and chemical composition of slime polysaccharide of $X$. campestris pv. oryzae were investigated.

\section{Materials and Methods}

Isolates. Eight colony variants derived from 3 isolates of $X$. campestris pv. oryzae were used (Table 1).

Isolation of slime polysaccharide and Pronase treatment. The methods for isolation of slime polysaccharide and Pronase treatment were as follows ${ }^{6)}$. The bacteria cultured on PSA medium ${ }^{5}$ in Roux Bottles at $25 \mathrm{C}$ for 3 days were suspended in $40 \mathrm{ml}$ of distilled water and shaken thoroughly. The bacterial cells were harvested by centrifugation at $26,000 \times g$ for $30 \mathrm{~min}$. The supernatant was transferred to a flask and three volumes of $95 \%$ cold ethanol was slowly added with stirring. The precipitate was collected by centrifugation at $6,000 \times g$ for $20 \mathrm{~min}$, washed twice, first with $95 \%$ ethanol and next with absolute ethanol, and finally dried at $50 \mathrm{C}$. The dried polysaccharide was dissolved in $0.1 \mathrm{M}$ tris-buffer, $\mathrm{pH} 7.4$, to obtain a final concentration at $5 \mathrm{mg} / \mathrm{ml}$. Pronase (Kaken Chemical Co. Ltd.) was added at a concentration of $1 \mathrm{mg} / \mathrm{ml}$ and incubated at $37 \mathrm{C}$ for $12 \mathrm{hr}$. The digest was then dialyzed for $24 \mathrm{hr}$ against 40 volumes of distilled water. To the supernatant obtained by centrifugation at $12,000 \times g$ for 30 min was added three volumes of $95 \%$ cold ethanol. The precipitate was washed with

Table 1. The relationships among serovar, colony type and virulence of the clones of $X$. campestris pv. oryzae used in this experiment

\begin{tabular}{lccr}
\hline \multicolumn{1}{c}{ Clone } & Serovar $^{\mathrm{a}}$ & Colony type $^{\mathrm{a})}$ & Virulence $^{(\mathrm{cm})^{\mathrm{b}}}$ \\
\hline Q7472-Lw-1 & A & Lw & 13.0 \\
Q7472-Lh-5 & B-I & Lh & 3.5 \\
Q7472-St-1 & B-II & St & 0 \\
Q7447-Lw-1 & A & Lw & 16.0 \\
Q7447-Sm-1 & B-II & Sm & 7.0 \\
N2-Lw-1 & A & Lw & 10.7 \\
N2-Ld-1 & B-I & Ld & 3.0 \\
N2-St-1 & B-II & St & 0 \\
\hline
\end{tabular}

a) Choi et al. ${ }^{3)}$

b) Choi et $a l .{ }^{8}$ 
$95 \%$ cold ethanol. The final precipitate was dried at $50 \mathrm{C}$.

Wilt induction by slime polysaccharide. Cuttings of 3 -week old rice seedlings were placed in tap water for an hour before use. Four concentrations of aqueous solution ranging from one to $1,000 \mathrm{ppm}$ of the slime polysaccharide were prepared. Five $\mathrm{ml}$ of each solution was poured into micro-tubes, and cuttings of rice seedling were inserted. The test tubes were held at temperatures ranging from 20 to $25 \mathrm{C}$ for $24 \mathrm{hr}$ in shadow.

Fractionation of slime polysaccharide. Slime polysaccharide of $X$. campestris pv. oryzae was chromatographed on a column $(1.7 \times 47 \mathrm{~cm}$ ) of Sephadex G-200 (Pharmacia Fine Chem. Co.) and eluted with distilled water ${ }^{27)}$ at a flow rate of $10 \mathrm{ml} / \mathrm{hr}$. The amount of polysaccharides eluate in each fraction $(2 \mathrm{ml})$ was determined by phenol-sulfuric acid method $^{11)}$.

Acid hydrolysis. Slime polysaccharides $(10 \mathrm{mg})$ were hydrolyzed in sealed tubes containing $3 \mathrm{ml}$ of $1 \mathrm{~N} \mathrm{H}_{2} \mathrm{SO}_{4}$ at $100 \mathrm{C}$ for $5 \mathrm{hr}$, and after cooling, the hydrolysates were neutralized with a saturated solution of $\mathrm{Ba}(\mathrm{OH})_{2}$. After centrifugation at $8,000 \times g$ for $20 \mathrm{~min}$, the supernatants were collected and freeze-dried.

Analysis of sugar residue by gas-liquid chromatography. Sugar components of slime polysaccharide were analyzed by the method of Sweeley et al. ${ }^{29)}$ Hydrolyzed slime polysaccharide was treated with $1 \mathrm{ml}$ of anhydrous pyridine, $0.2 \mathrm{ml}$ of hexamethyldisilazane, and $0.1 \mathrm{ml}$ of trimethylchlorosilane. The mixture was shaken vigorously for about $30 \mathrm{sec}$ and then warmed at 75 to $85 \mathrm{C}$ for 2-3 min. A Shimazu Model GC-7AG gas chromatograph with hydrogen flame ionization detector was used. The temperature of injection port was $270 \mathrm{C}$. Column temperatures were changed from 140 to $240 \mathrm{C}$ at $4 \mathrm{C} / \mathrm{min}$. One microliter of the sample was injected. Identification of sugars, glucuronolactone and glucuronic acid was based on co-chromatography with known standards. Sugar ratio was automatically shown on "Chromatopac" (Shimazu Model C-RIA) as peak area.

Quantitative precipitin inhibition assay. One $\mathrm{ml}$ of sugar solution $(100 \mathrm{mg} / \mathrm{ml})$ was incubated with $1 \mathrm{ml}$ of diluted (1:10 in saline) antiserum at $37 \mathrm{C}$ for $1 \mathrm{hr}$. One $\mathrm{ml}$ of the polysaccharide solution $(2 \mathrm{mg} / \mathrm{ml})$ in saline was then added to the reaction mixture, further incubated at $37 \mathrm{C}$ for $1 \mathrm{hr}$ and kept overnight at $4 \mathrm{C}$. The mixtures were centrifuged at $6,000 \times g$ for $20 \mathrm{~min}$ and washed three times with $0.85 \% \mathrm{NaCl}$ solution. The pellet was dissolved in $1 \mathrm{ml}$ of $0.1 \mathrm{~N} \mathrm{NaOH}$ and optical density of the solution was determined at $287 \mathrm{~nm}^{18)}$.

\section{Results}

\section{Wilting effect of slime polysaccharide on rice cuttings}

The cuttings of rice seedlings placed in colloidal solution of slime polysaccharide of $X$. campestris pv. oryzae exhibited wilting symptom within $2 \mathrm{hr}$ and were completely wilted by the end of $12 \mathrm{hr}$ incubation. The rapidity and severity of the wilting were correlated with concentration of polysaccharide but not with colony type or virulence (Table 2). Rice cuttings wilted after $2 \mathrm{hr}$ at $1,000 \mathrm{ppm}, 12 \mathrm{hr}$ at 10 to $100 \mathrm{ppm}$ and weak or no symptom was observed at $1 \mathrm{ppm}$. 
Table 2. The effect of slime polysaccharide of $X$. campestris pv. oryzae on the induction of wilting in rice cuttings ${ }^{a)}$

\begin{tabular}{|c|c|c|c|c|c|}
\hline \multirow{2}{*}{ Clone and isolate } & \multirow{2}{*}{ Serovar } & \multicolumn{4}{|c|}{ Concentration (ppm) } \\
\hline & & 1,000 & 100 & 10 & 1 \\
\hline Q7472-Lw-1 & A & $W^{b)}$ & $H$ & + & \pm \\
\hline Q7472-St-1 & $\mathrm{B}-\mathrm{II}$ & H & $H$ & + & \pm \\
\hline Q7447-Ld-1 & B-I & H & $H$ & + & \pm \\
\hline Q7447-Sm-1 & B-II & H & $H$ & + & \pm \\
\hline Q7502 & B-I & H & $H$ & + & \pm \\
\hline N5837 & B-II & H & $H$ & + & \pm \\
\hline
\end{tabular}

a) Twelve hr after dipping in slime polysaccharide solution.

b) $\mathbb{H} \sim$ : Severity of wilting.

\section{Fractionation of slime polysaccharide}

The soluble slime polysaccharide was precipitated in $95 \%$ ethanol, treated with Pronase, dialyzed against water, precipitated with ethanol and dried at $50 \mathrm{C}$. The crude slime polysaccharide from each clone was fractionated on a gel permeation column, and the amount of polysaccharide in eluate was measured with phenol-sulfuric acid method ${ }^{11)}$. The molecular size of polysaccharides of each clone was distributed in wide range, and

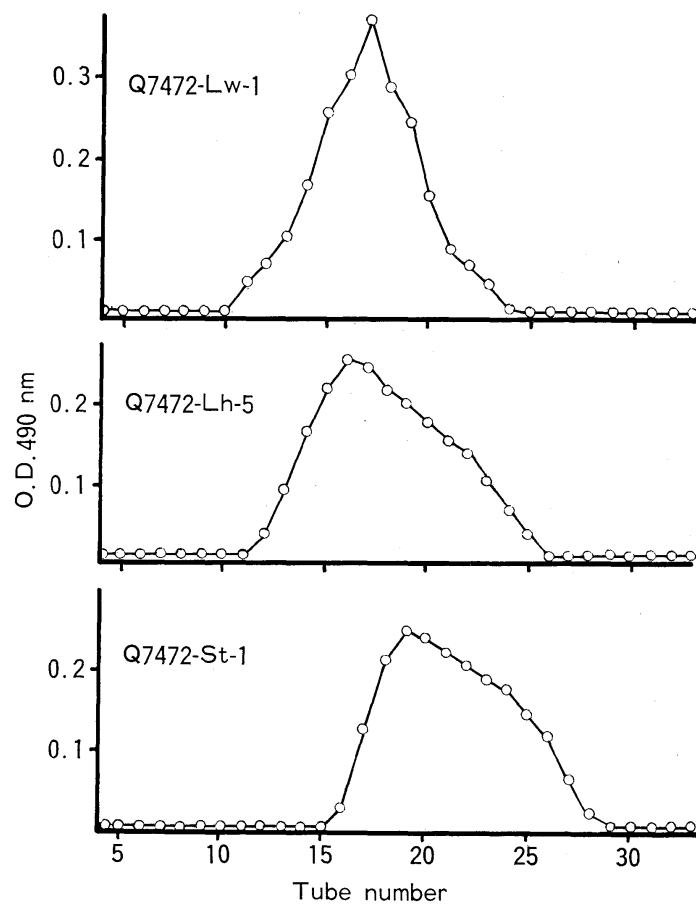

Fig. 1. Sephadex G-200 chromatography of the slime polysaccharides obtained from the clones of $X$. campestris pv. oryzae different in virulence. the ratio of high- and low-molecular weight polysaccharide in each clone was also different.

The clone Q7472- $\mathrm{Lw}^{-1}$ (large colony type and virulent) excreted relatively high-molecular polysaccharides whereas Q7472-St-1 (small colony type and avirulent) excreted relatively low-molecular polysaccharides. The clone Q7472-Lh-5 (large colony with halo and weakly virulent), however, showed intermediate pattern between $\mathrm{Lw}_{-1}-1$ and $\mathrm{St}-1$ (Fig. 1).

The fractions containing antigen "a" were identified by the ordinary agar gel diffusion test against antiQ7472-serum. Most of the fractions from Q7472-Lw-1 formed precipitin band "a" while all fractions of Q7472Lh-5 and Q7472-St-1 did not.

\section{Chemical composition of slime polysaccharide}

Gas-liquid chromatograms of the sugars obtained from the hydrolysis 
of slime polysaccharide of $X$. campestris pv. oryzae showed five peaks (Fig. 2). The peaks were arabitol, mannose, glucuronolactone, glucose and glucuronic acid. The slime polysaccharide from all colony types had the same monomeric components. Glucose, mannose and glucuronic acid were the major monomers detected in the slime polysaccharide of all types with small amounts of glucuronolactone and arabitol (Table 3). Significant difference was not observed among $\mathrm{Lw}, \mathrm{Lh}$ and $\mathrm{Ld}$ types in the contents of these major monomers. In St type, however, the major sugar of arabitol was particularly higher than in $\mathrm{Lw}, \mathrm{Ld}$ and $\mathrm{Lh}$ types.

The molar ratios of arabitol, glucose, mannose, glucuronic acid and glucuronolactone in the slime polysaccharide of Q7472-Lw-1 (serovar A) were 0.8, 37.5, $30.2,30.7$ and 0.8 , while in that of Q7472St-1 (serovar B-II) they were 7.6, 41.0, $20.4,26.5$ and 4.5 , respectively. In general, the ratio of mannose and glucuronic acid were greater and those of arabitol and glucuronolactone were much smaller in the slime polysaccharide from large colony

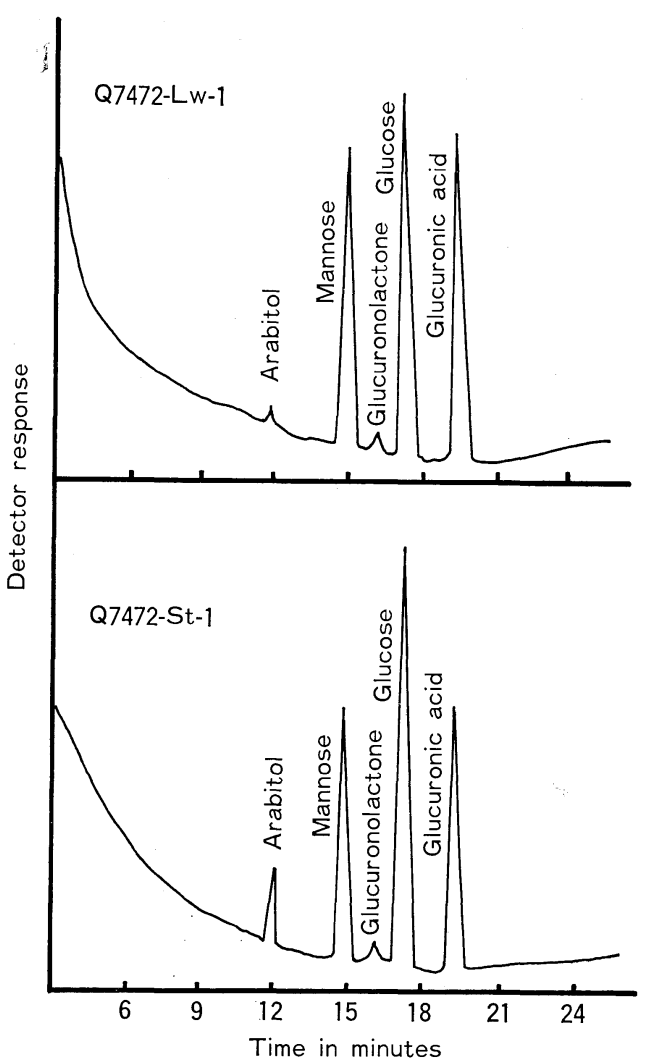

Fig. 2. Chromatogram of TMS-derivatives of acid-hydrolyzed slime polysaccharide of $X$. campestris pv. oryzae. types as compared to small colony types.

\section{Quantitative precipitin inhibition assay}

Serological identity of antigens is an expression of similarity in serological determinants. To characterize specificity of the slime polysaccharide antigen, quantitative precipitin inhibition studies were conducted. Component sugars of slime polysaccharides were used

Table 3. Component sugars of slime polysaccharide of $X$. campestris pv. oryzae

\begin{tabular}{lccccc}
\hline \multicolumn{1}{c}{ Clone } & Arabitol & Mannose & Glucuronolactone & Glucose & Glucuronic acid \\
\hline Q7472-Lw-1 & $0.8 \%$ & $30.2 \%$ & $0.8 \%$ & $37.5 \%$ & $30.7 \%$ \\
Q7472-Lh-5 & 1.1 & 30.0 & 1.1 & 37.7 & 30.1 \\
Q7472-St-1 & 7.6 & 20.4 & 4.5 & 41.0 & 26.5 \\
\hline N2-Lw-1 & 0.2 & 28.5 & 0.6 & 36.8 & 33.9 \\
N2-Ld-1 & 0.7 & 26.6 & 0.7 & 38.8 & 33.2 \\
N2-St-1 & 15.6 & 24.3 & 3.0 & 41.1 & 16.0 \\
\hline Q7447-Lw-1 & 0.2 & 31.4 & 1.0 & 33.3 & 34.1 \\
Q7447-Sm-1 & 0.7 & 21.9 & 1.1 & 43.1 & 33.2 \\
\hline
\end{tabular}


Table 4. Precipitin inhibition by component sugars of $X$. campestris pv. oryzae polysaccharide

\begin{tabular}{llrrrrr}
\hline $\begin{array}{c}\text { Inhibitor } \\
(100 \mathrm{mg} / \mathrm{ml})\end{array}$ & \multicolumn{2}{c}{$\begin{array}{c}\text { Q7472 } \\
\text { (serovar A) }\end{array}$} & \multicolumn{2}{c}{$\begin{array}{c}\text { Q7502 } \\
\text { (serovar B-I) }\end{array}$} & \multicolumn{2}{c}{$\begin{array}{c}\text { N5837 } \\
\text { (serovar B-II) }\end{array}$} \\
\hline Arabitol & $0.66^{\mathrm{a}}$ & $0^{\mathrm{b})}$ & 0.26 & 7.2 & 0.27 & 3.5 \\
Glucose & 0.39 & 40.9 & 0.27 & 0.1 & 0.28 & 0 \\
Mannose & 0.51 & 22.7 & 0.30 & +7.1 & 0.29 & +3.5 \\
Glucuronic acid & 0.56 & 15.2 & 0.90 & +121.4 & 1.28 & +357.1 \\
Glucuronolactone & 0.70 & +6.1 & 1.33 & +327.0 & 1.11 & +326.8 \\
NaCl & 0.66 & 0 & 0.28 & 0 & 0.28 & 0 \\
\hline
\end{tabular}

a) Determined at $287 \mathrm{~nm}$.

b) Inhibition or promotion (\%), + : Promotion.

to inhibit the precipitation with anti-Q7472-serum. The results are shown in Table 4 .

In the cases of Q7502 and N5837 which belong to serovar B, 121.4-375.0\% promotion of precipitin reaction was observed with glucuronolactone and glucuronic acid, while promotion effect was not so remarkable with glucose, arabitol and mannose. In the case of Q7472 belonging to serovar A, the results were remarkably different showing high inhibition with glucose, mannose and glucuronic acid.

\section{Discussion}

The slime polysaccharides of $X$. campestris pv. oryzae induced wilting in rice seedling. However, there was no difference in wilt inducing potential between the slime polysaccharides of virulent and avirulent isolates. These results indicate that wilting is not specific and could be caused by the plugging with polysaccharides produced by the parasite which is compatible with the host. Hogdson et al. ${ }^{16)}$ observed two types of wilting in tomato plant cuttings: one affecting the leaflet margins which was caused by relatively small molecular weight substances like inulin, soluble starch, glucosan from crown gall bacteria and carbowax $(1,500$ and 3,000) and the other type affecting stems and petioles which was caused by macro-molecular substances as xylan, pectin and carbowax 6,000 and 9,000 .

Since the virulence of $X$. campestris pv. oryzae isolates are closely related to the amount of polysaccharides production, the wilting of rice seedlings can partially be attributed to a similar molecular plugging. However, the differences in molecular size and molar ratio of component sugars seem to be related to virulence in the case of $X$. campestris pv. oryzae. Kuo et al. ${ }^{20)}$ and Angadi ${ }^{1)}$ already reported that $X$. campestris pv. oryzae produced polysaccharides which were capable of inducing wilting in plant cuttings. The molecular weights of these substances were reported to be 200,000 or bigger with glucose and mannose making up most of their weight ${ }^{20)}$.

The chemical composition of slime polysaccharide described in this paper mainly agreed with that in earlier reports ${ }^{1,20,22,28)}$ with some minor differences. Slime polysaccharide of clones showing different colony types or serovars was the same in chemical components. Each contains five sugars such as arabitol, mannose, glucuronolactone, glucose and glucuronic acid. The molar ratios of these sugars were remarkably different 
depending upon serovars or colony types.

Misaki et al. ${ }^{22)}$ and Angadi ${ }^{1)}$ isolated slime polysaccharide from $X$. campestris pv. oryzae with Fehling solution. However, we found out that this method was unsuitable for serological test, because the polysaccharide obtained by this method lost its serological properties ${ }^{8)}$ indicating that slime polysaccharide might have been denatured.

The ratio of component sugars may reflect the structure of slime polysaccharide. Arabitol and glucose contents were higher in slime polysaccharide of small colony types (avirulent) than in those of large colony types. These differences could directly or indirectly reflect on the structural, serological, morphological and pathogenic differences of $X$. campestris pv. oryzae.

Iacono et al. ${ }^{18)}$ and others ${ }^{21,23)}$ analyzed immunodominant region of the antigen by hapten inhibition studies in Streptococcus. Similar experiments were also conducted by Jann et al. ${ }^{19)}$ and Nhan et al. ${ }^{24)}$ According to the report by Jann et al., partial structures of an antigen which inhibit the homologous serological system also fulfil the requirements for inhibition in a cross reacting system.

The hapten inhibition studies were also carried out in our experiment by using sugars of slime polysaccharide component and anti-Q7472-serum. In the case of Q7472, glucose, mannose and glucuronic acid inhibited precipitin reaction. These sugars, therefore, seem to constitute a major portion of the immunogenic region of serovar-specific antigen. In the cases of Q7502 (serovar B-I) and N5837 (serovar B-II), remarkable promotion effect was observed with glucuronic acid and glucuronolactone. Supposedly, the promotion effect also suggests some correlations with component sugars, but its mechanism is unknown.

\section{Literature cited}

1. Angadi, C. V. (1978). Phytopath. Z. 93 : 170-180.

2. Ayers, A. R., Ayers, S. B. and Goodman, R. N. (1979). Appl. Environ. Microbiol. 38: 659-666.

3. Buddenhagen, I. and Kelman, A. (1964). Ann. Rev. Phytopathol. 2: 203-230.

4. Cadmus, M. C. Rogovin, S. P., Burton, K. A., Pittsley, J. E., Knutson, C. A. and Jeanes, A. (1976). Can. J. Microbiol. 22 : 942-948.

5. Choi, J. E., Matsuyama, N. and Wakimoto, S. (1980). Ann. Phytopath. Soc. Japan 46: $209-215$.

6. Choi, J. E., Matsuyama, N. and Wakimoto, S. (1981). Ibid. 47 : 199-205.

7. Choi, J. E., Matsuyama, N. and Wakimoto, S. (1981). Ibid. $47: 244-251$.

8. Choi, J. E., Matsuyama, N. and Wakimoto, S. (1981). Ibid. $47:$ 668-676.

9. Corey, R. R. and Starr, M. P. (1957). J. Bacteriol. 74 : 137-140.

10. Cross, J. E. and Goodman, R. N. (1973). Phytopathology 63: 1425-1426.

11. Dubis, M., Gilles, K. A., Hamilton, J. K., Rebers, P. A. and Smith, F. (1956). Anal. Chem. 28: 350-356.

12. Eden-Green, S. T. and Knee, M. (1974). J. Gen. Microbiol. 81 : 509-512.

13. Fan, H. N. and Kuo, T. T. (1972). Bot. Bull. Acad. Sinica 13: 111-117.

14. Goodman, R. N., Huang, J. S. and Huang, P. Y. (1974). Science 183: 1081-1082.

15. Gorin, P. A. J. and Spencer, J. F. T. (1963). Can. J. Chem. 41: 2357-2361.

16. Hogdson, R., Peterson, W. H. and Riker, A. J. (1949). Phytopathology 39: 47-62.

17. Husain, A. and Kelman, A. (1958). Ibid. 48: 155-165.

18. Iacono, V. J., Taubman, M. A., Smith, D. J. and Levine, M. J. (1975). Infect. Immun. 11: 117128.

19. Jann, K., Jann, B. and Schneider, K. F., Фrskov, F. and Фrskov, I. (1968). Eur. J. Biochem. $5: 455-465$.

20. Kuo, T. T., Lin, B. C. and Li, C. C. (1970). Bot. Bull. Acad. Sinica 11: 46-54. 
21. Linzer, R. and Slade, H. D. (1974). Infect. Immun. 10: 361-368.

22. Misaki, A., Kirkwood, S., Scaletti, J. V. and Smith, F. (1962). Can. J. Chem. 40: 2204-2213.

23. Mukas, H. and Slade, H. D. (1973). Infect. Immun. $7: 578-585$.

24. Nhan, Le-Ba., Jann, B. and Jann, K. (1971). Eur. J. Chem. 21: 226-234.

25. Sequeira, L. and Graham, T. L. (1977). Physiol. Plant Pathol. 11: 43-54.

26. Smith, H. (1977). Bacteriol. Rev. 41: 475-500.

27. Strobel, G. A. (1967). Plant Physiol. 42: 1433-1441.

28. Sutton, J. C. and Williams, P. H. (1970). Can. J. Bot. 48: 645-651.

29. Sweeley, C. C., Bentley, R., Makita, M. and Wells, W. W. (1963). J. Am. Chem. Soc. 85 : $2497-$ 2507.

30. Tabei, H. (1968). Ann. Phytopath. Soc. Japan 34:137-139.

31. Van Alfen, N. K. and Turner, N.C. (1975). Plant Physiol, 55: 312-316.

\section{和 文 摘 要}

\section{イネ白葉枯病菌粘液多糖質の生物学的㐨よび化学的性質}

\section{崔 在乙・松山宣明・脇本 哲}

イネ白葉枯病菌の培養ろ液からェタノール沈殿によって得られた粘液多糖質はイネ幼苗を萎らょらさせる が，濃度を同一にした場合には血清型の異なるクローン間にも活性の差は認められなかった。各クローンの 粘液多糖質は血清型に関係なくいずれもアラビトール，マンノース，グルクロノラクトン，グルコースおよ

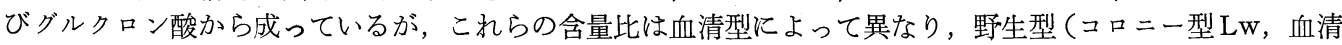
型A）の粘液多糖質では変異型（コロニ一型 St，血清型 B-II）のそれよりもアラビトール，グルコースおよ びグルクロノラクトンの含量比が小であった。また血清型 Aの産生する粘液多糖質は血清型 B-II 変異株の産 生するそれに比べて高分子量のものの含量が相対的に大であった。粘液多糖質の各構成糖を用いて粘液多糖 質の凝集反応抑制実験を行った結果，血清型 $\mathrm{A}$ の凝集反応はグルコース，マンノース，拉よびグルクロン酸 によって著しく抑制されたが，血清型 B-I および B-II の場合にはグルクロン酸とグルクロノラクトンによっ て反応が著しく促進された。これらの結果は血清型によって主要免疫部分の構成糖に顕著な差があることを 示唆するものと考えられる。 